DOI: 10.25178/nit.2017.4.5

\section{ЭКОНОМИКА СОВЕТСКОЙ ТУВЫ: ДОСТИЖЕНИЯ, ПРОБЛЕМЫ И УРОКИ}

\author{
Александр Д. Бегзи \\ Независимый автор, \\ Российская Федерация
}

\section{THE ECONOMY OF THE SOVIET TUVA: ACHIEVEMENTS, CHALLENGES AND LESSONS}

\author{
Aleksandr D. Begzi \\ Independent researcher, \\ Russian Federation
}

\begin{abstract}
Экономика Тувы в советское время, с 1944 по 1991 г2., развивалась высокими темпами. За счет государственных инвестиций создавались предприятия и цзелые отрасли производства, были намечены контуры специализации республики. Экономические показатели были выше, чем в среднем по стране. Созданная производственная инфраструктура - транспортная, энергетическая, инженерная - используется без серьезной реконструкции в течение многих лет.
\end{abstract}

Однако хозяйство Тувы благополучно функциионировало только в условиях директивного планирования, государственного регулирования цен, потоков ресурсов и товаров, других атрибутов социалистической плановой экономики. Эти проблемы наряду с особенностями хозяйства обусловили неустойчивость экономики Тувы.

Анализ экономических достижений и проблем советской Тувы, сложившихся в тот период, позволяет извлечь уроки, которые следует учесть при разработке долгосрочных программ. Хотя действие программных документов, принятых в начале 2000-х годов, в частности, Стратегии социально-экономического развития Республики Тыва до

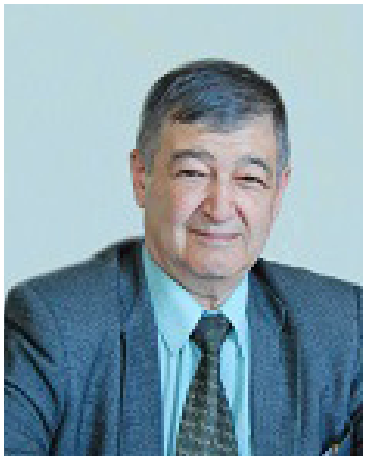

In the Soviet period (1944-1991), the economy of Tuva was rapidly developing. Massive state investment helped create enterprises and whole branches of industry, which in turn outlined the areas of economy Tuva could specialize in. Indicators of regional economic development were higher than the national average. The industrial infrastructure created over the period, including transport, power engineering and technologies, has been since used for several decades without major renovations.

However, the smooth function of the regional economy could be guaranteed only under directive planning and stringent control over prices, flows of resources, goods and other assets of planned Socialist economy. Together with other specific features of its economy, this made the economy of the region highly volatile.

A breakdown of both economic achievements of the Soviet Tuva and the problems it faced will help us learn the lessons to be accounted for while developing new long-term development programs.

Бегзи Александр Донгакович - независимый автор; экономист, министр экономики Республики Тыва (1994-1997), советник мэра г. Кызыла, г. Кызыл, Российская Федерация. Адрес: 667000, Россия, г. Кызыл, ул. Ленина, д. 32. Эл. адрес: bad_tuva@mail.ru

Begzi Aleksandr Dongakovich, Independent Researcher, economist, Minister of Economy, Republic of Tuva (1994-1997), adviser of the Mayor of Kyzyl, Russian Federation. Postal address: 32 Lenin St., 667000 Kyzyl, Russian Federation.E-mail: bad_tuva@mail.ru 
2020 года (2007 г.) еще не завершилось, экономическая конъюнктура, конфигурация действующих в Туве основных хозяйствующих субъектов изменились таким образом, что возникла необходимость обновления долгосрочной стратегии социальноэкономического развития. Некоторые проявивщиеся еще в советское время проблемы усугубились, другие превратились в свою противоположность. Формируемые в Туве доходы консолидированного бюджета, как и в советское время, не позволяют в полном объеме обеспечивать функционирование социальной сферы. Очевидно, что большая часть применяемых в советский период механизмов развития экономики в настоящее время не действует и необходимо применение иных организационных и финансовых инструментов.

Источниками для написания статьи выступили официальные издания органов статистики Республики Тыва, а также материалы региональных научно-практических конференций и совещаний, посвященных социально-экономическому развитию тувы.

Ключевые слова: Тува; советская история; история Тувы; экономика; дотационность; экономическое развитие; стратегия развития
Although the programmatic documents adopted in early 2000s (such as the Strategy of social and economic development of the Republic of Tuva to the year 2020, passed in 2007) have not yet expired, the economic situation and the configuration of the main economic actors have seriously changed, which calls for a radical overhaul of the long-term strategy of social and economic development. Some problems which have been around since the Soviet times have grown more acute, while others were replaced by their opposites. The revenue section of the region's consolidated budget, just as it was in the Soviet period, cannot fully provide the required social expenditures. At the same time, the majority of Soviet mechanisms of economic development are now totally dysfunctional, which calls for the use of new organizational and financial instruments.

The article was based on the data from official statistical collections of the Republic of Tuva, and the information found in the proceedings of regional meetings and conferences on the various issues of Tuva's social and economic development.

Keywords: Tuva; Soviet history; history of Tuva; economy; regional development subsidies; economic development; development strategy

\section{Введение}

Поскольку как политические, так и социально-экономические процессы в Тувинской Народной Республике развивались по советской модели, адаптация ее экономики к функционированию в составе хозяйственного комплекса СССР произошла без существенных эксцессов и катаклизмов. Преобразование экономических отношений не было приоритетом (за исключением аграрного сектора), главным направлением было реформирование материально-технической и технологической базы и встраивание региональной системы управления в единую плановую систему страны.

Стартовый уровень экономики Тувы был довольно низок, поэтому со стороны государства осуществлялись специальные меры поддержки, которые формулировались в адресных постановлениях ЦК КПСС, Совета Министров СССР, Совета Министров РСФСР, в том числе постановления Совета Министров СССР «О мерах помощи сельскому хозяйству Тувинской автономной области» (1949 г.), «О мерах по дальнейшему выявлению минерально-сырьевых ресурсов в Тувинской автономной области (1950 г.), постановление Совета Министров РСФСР «О мерах по дальнейшему развитию овцеводства в Тувинской АССР» (1973 г.). Наиболее масштабными были постановления ЦК КПСС и Совета Министров СССР «О мерах по дальнейшему комплексному развитию производи- 
тельных сил Тувинской АССР» (1976 г.) и «О мерах по ускорению экономического и социального развития Тувинской АССР» (1985 г.). Принимались также решения министерств и ведомств СССР и РСФСР по отдельным вопросам развития соответствующих отраслей.

Советскому периоду ${ }^{1}$ развития экономики Тувы посвящено немало научных работ разного формата, в том числе монография «Экономика Тувинской АССР» (Экономика Тувинской АССР, 1973), разделы монографий «История Тувы» 1964 г. (История Тувы, 1964) и недавнего издания (История Тувы, 2016), в работе Г. Ф. Балакиной и автора данной статьи (Балакина, Бегзи, 2016), а также множество научных статей. Тем не менее, не будет лишним перечислить забытые за постсоветские годы экономические достижения Тувы, проанализировать проблемы того времени и сделать попытку извлечь уроки, учет которых полезен при формировании долговременной стратегии социально-экономического развития.

При подготовке статьи были использованы официальные издания органов статистики Республики Тыва (Тува за 80 лет, 2001; Республика Тыва ..., 2011; Юбилейный ..., 2014), а также материалы региональных научно-практических конференций и совещаний представителей академических и отраслевых НИИ, а также органов управления СССР, РСФСР и Тувы (Труды регионального ..., 1960; Развитие народного ... , 1975; Проблемы комплексного ... , 1981; Проблемы развития ..., 1988).

\section{Формирование многоотраслевой экономики советского региона}

Первоочередной задачей было создание адекватной имеющимся потребностям системы жизнеобеспечения - энергоснабжения, коммунальной инфраструктуры, развитие производства товаров народного потребления, обеспечивающего хотя бы первичные нужды населения. Поскольку большинство промышленных предприятий Тувы к середине 1940-х годов представляло собой полукустарные производства, требовалась их модернизация с существенным расширением производства, некоторые отрасли было необходимо создавать заново.

Транспортная изолированность диктовала необходимость создания максимально возможного набора промышленных отраслей и производств. Приведение сельского хозяйства Тувы к советскому стандарту требовало проведения коллективизации и создания крупных коллективных и государственных сельхозпредприятий. Определяющим условием динамичного развития всех отраслей было создание строительной базы.

${ }^{1}$ Для целей этой статьи рамки советского периода Тувы определяются с момента официального вхождения Тувинской Народной Республики в состав СССР в октябре 1944 г. - до конца 1991 г. 
Благодаря значительным государственным инвестициям темпы промышленного роста в Туве значительно опережали средние показатели по стране. Общий объем промышленного производства в целом за советский период возрос в 87,8 раза, а в отдельных отраслях - энергетика, топливная, производство стройматериалов, - темпы были значительно выше.

Большое внимание уделялось развитию топливно-энергетического комплекca. В 1944 г. показатель выработки электроэнергии в расчете на душу населения был в 25-30 раз ниже, чем в среднем по стране. Объем генерации не позволял обеспечивать даже бытовые нужды городского населения, не говоря уже о применении в производстве. К концу 1950-х годов количество локальных энергоустановок увеличилось с 7 до 190 единиц. В 1959 г. дала ток первая очередь Кызылской паротурбинной электростанции, в 1961 г. введена в эксплуатацию ТЭЦ комбината «Тувакобальт», в 1963 г. - ТЭЦ комбината «Туваасбест». Принципиально важным для Тувы стал ввод ЛЭП-220 кВ Абаза - Ак-Довурак, а затем Шушенское - Кызыл. Возрастала протяженность разводящих сетей.

Для выработки тепловой энергии требовалось наращивать добычу угля. Вступили в строй шахта «Красная горка», Чаданский, затем Каа-Хемский угольный разрезы. В 1945 г. было добыто всего 6,5 тыс. т, в 1960-м - 112 тыс. т., а в 1990 г. уже более 1 млн т. Добываемый уголь практически полностью использовался энергетическими предприятиями, котельными промышленных, сельскохозяйственных и других организаций Тувы.

В связи с ростом населения, особенно, городского, увеличивался выпуск продукции пищевой промышленности. В 1950-1960-х гг. в Кызыле были введены хлебозавод и молокозавод, пивоваренный завод, мельница, появились Кызылский и Кызыл-Мажалыкский мясокомбинаты. В Чадане, Ак-Довураке, Шагонаре, других райцентрах были открыты предприятия пищевой промышленности, в основном входящие в систему потребкооперации. В продажу поступили мясные и молочные продукты промпереработки, мука, увеличился выпуск хлеба и кондитерских изделий. К концу 1980-х гг. предприятия пищевой промышленности обеспечивали около половины объема потребностей населения в продуктах питания.

Довольно быстро увеличивалось производство непродовольственных товаров. К старейшим предприятиям легкой промышленности - кожевенно-пимокатному заводу и швейной фабрике - в 1980-е годы добавились филиал швейной фабрики в пос. Хову-Аксы, Ак-Довуракская швейно-трикотажная фабрика и другие производства. Действовали 2 мебельные фабрики, предприятие народно-художественных промыслов в Кызыле, в районных центрах работали промышленные комбинаты и комбинаты бытового обслуживания, выпускавшие одежду и обувь. В 1987 г. в рамках общегосударственной кампании в Туве была разработана программа увеличения производства товаров народного потребления и оказания платных услуг. Хотя речь шла в большей мере о легализации продажи населению продукции деревообработки, стройиндустрии, иных 
непрофильных предприятий, а также услуг строительных, транспортных и других организаций, чем о реальном росте, реализация этого проекта способствовала более полному насыщению рынка.

Оснащение предприятий оборудованием потребовало создания базы для обслуживания и ремонта транспортной, сельскохозяйственной и другой техники. В Кызыле начал работать автомобильно-ремонтный завод, в начале 1960-х гг. в Кызыле и районных центрах появились предприятия объединения «Сельхозтехника». Позже был построен Тувинский машиностроительный завод.

Наряду с развитием производств, обеспечивающих внутренние потребности населения и хозяйства, были сделаны первые шаги и по формированию отраслей межрегиональной специализации Тувы. Уже в 1940-1950-е гг. было признано и затем неоднократно подтверждено, что отраслями специализации экономики в перспективе должны стать горнодобывающие производства. В результате масштабных геологоразведочных работ были открыты месторождения железных руд, коксующихся и энергетических углей, асбеста, цветных металлов, каменной соли, в том числе Кызыл-Таштыгское полиметаллическое, Хову-Аксынское медно-никель-кобальтовое, Терлиг-Хаинское ртутное, АкСугское медно-молибденовое, Улуг-Танзекское тантал-ниобиевое, месторождения и рудопроявления железных руд, углей, асбеста, каменной соли и др.

В сентябре 1964 г. введена в эксплуатацию первая очередь горно-обогатительного комбината «Туваасбест». В первый год его работы было добыто 11,8 тыс. т. хризотил-асбеста. После ввода второй очереди выпуск асбеста ежегодно увеличивался и в 1990 г. был достигнут максимальный объем производства в 135 тыс. т. Создание крупного производства и вспомогательных и строительных организаций стало причиной появления нового города Ак-Довурака, быстро ставшего вторым из городов Тувы по численности населения.

В 1970 г. начал работать комбинат «Тувакобальт» на базе Хову-Аксынского месторождения. В его состав входили Терлиг-Хаинское предприятие по добыче ртути и золотодобывающие артели. Этот комбинат стал градообразующим предприятием для пгт Хову-Аксы.

Ак-Довурак и Хову-Аксы были, по сути, «моногородами», со всеми особенностями таких поселений.

Сельскохозяйственное производство Тувы в 1940-е годы было главной, в большинстве районов единственной отраслью хозяйства. Более $90 \%$ населения было занято в животноводстве и земледелии. При этом мясо, молоко, кожевенное сырье, картофель и даже зерно в основном потреблялись внутри домохозяйств. По стандартной советской модели в 1950-е гг. было осуществлено объединение крестьян в коллективные хозяйства с созданием предприятий, оснащенных передовой техникой того времени. Быстро увеличивался парк сельскохозяйственных машин и грузовых автомобилей. С 1945 г. развернулось строитель- 
ство машинно-тракторных станций (MTC), первая из которых появилась в БайХааке, затем МТС были организованы в Туране, Шагонаре, Сарыг-Сепе, Чадане, к 1950 г. они работали уже во всех районах.

Расширение посевных площадей за счет освоения целинных и залежных земель, применение техники и удобрений способствовали росту сборов зерна и других культур. Посевные площади с 61,4 тыс. га в 1945 г. увеличились в 19701980-е гг. до 350-370 тыс. га. Выращивались яровая и озимая пшеница, ячмень, рожь, овес, другие культуры. Самым урожайным за всю историю растениеводства Тувы был 1972 г., когда валовой сбор зерновых культур составил 298,1 тыс. тонн.

При этом урожайность была нестабильной, а растениеводство - низкорентабельным. Хотя сборы картофеля и овощей постоянно возрастали, полностью потребности Тувы не обеспечивались, приходилось эти продукты завозить из районов Сибири, а ранние сорта овощей - из среднеазиатских республик СССР.

Животноводство давало до 80\% объема сельскохозяйственной продукции. Важную, а в первые годы после вхождения Тувы в состав СССР определяющую, роль в отрасли играло личное подсобное хозяйство населения. В период проведения коллективизации поголовье скота в личной собственности сокращалось, что даже приводило к снижению общего поголовья. Тем не менее, в целом поголовье довольно быстро стабилизировалось, а за счет повышения продуктивности постоянно возрастало производство мяса, молока, шерсти.

По производству продукции сельского хозяйства на душу населения Тува достигала среднего по стране уровня, а по продукции животноводства - превосходила его.

Ежегодно расширялись масштабы капитального строительства. В первые годы после вхождения Тувы в состав России строительные объекты возводились строительными подразделениями при предприятиях, учреждениях и колхозах. В 1945 г. появилась первая крупная подрядная организация - трест «Тувинстрой», позже были образованы специализированные тресты «Тувинсельстрой», «Тувинводстрой», «Тувинремстрой», «Росколхозстрой, «Шагонартяжстрой»; в Ак-Довураке - «Туваасбестстрой». В 1985-1990 гг. на строительстве объектов в Туве трудились строители из Башкирской АССР, Алтайского и Красноярского краев и ряда областей РСФСР, привлечение которых было предусмотрено постановлением ЦК КПСС и Совета Министров СССР.

Объемы капитальных вложений и ввод основных фондов ежегодно возрастали. Были построены десятки промышленных предприятий, магистральные линии и разводящие электрические сети, инженерные сети в Кызыле, АкДовураке, Шагонаре и других городах.

Особенно быстрыми темпами велось строительство учреждений социальной сферы. Были построены школы на 66,6 тыс. мест, детские дошкольные уч- 
реждения на 14,7 тыс. мест, больничные учреждения на 2820 коек, учреждения культуры, спорта, санатории-профилактории на озерах Чедер, Уш-Бельдир и Дус-Холь, профилактории комбинатов «Туваасбест» и «Тувакобальт». Дальнейшее развитие получила сеть предприятий культурно-бытового, коммунального, торгового и других видов общественного обслуживания.

Стремительно нарастали масштабы жилищного строительства. Ввод жилья с 1 тыс. кв. м в 1945 г. возрос до 150,8 тыс. кв. м в 1990 г., а в целом за советский период было введено более 3 млн кв. м общей площади жилья. В 1970-1980-е гг. государственные капитальные вложения в жилищное строительство в расчете на 10 тыс. жителей в Туве в полтора-два раза превышали уровень РСФСР. Городской жилищный фонд к концу советского периода превысил 3,6 млн кв. м. Появились благоустроенные жилые микрорайоны и кварталы. Улучшалась планировка квартир, повышался уровень благоустройства. Обеспеченность жилья центральным отоплением, водопроводом и канализацией повысилась за 1960-1980 гг. с 10 до 65-70\%; в 1990 г. более 60\% жилищного фонда было оборудовано газовыми установками. Началось строительство жилья, оборудованного напольными электроплитами.

Расширение масштабов строительства требовало увеличения выпуска местных стройматериалов. В 1944 г. кирпичный завод в Кызыле и предприятия промкооперации выпустили всего 500 тыс. шт. кирпича. В 1960 г. было произведено уже 15 млн штук, после ввода предприятий в Кызыл-Мажалыке и Усть-Элегесте к 1990 г. выпуск достиг уже 45,3 млн. Производились железобетонные конструкции, был введен домостроительный комбинат. Увеличивались заготовки древесины и производство пиломатериалов. Динамика численности занятых в строительстве заметно опережала общие темпы роста работающих. Подготовка кадров строителей велась в Кызылском политехническом техникуме, филиале Красноярского политехнического института и ряде профессионально-технических училищ.

Важнейшим условием прогресса Тувы было развитие транспорта и дорожного хозяйства. Быстрыми темпами увеличивался парк грузового подвижного состава и легковых автомобилей, создавались новые транспортные организации. Самым крупным из них было управление «Туваавтотранс», в которое входили три автотранспортных предприятия в Кызыле, а также Ак-Довуракское, Чаданское, Минусинское АТП и др. Предприятия оснащались новой техникой автомобилями Урал, ЗИЛ, МАЗ, КамАЗ, мощными тягачами, автокранами. Это позволило ежегодно наращивать грузооборот и объем перевозок. За 1950-е гг. объем перевозок увеличился с 0,5 до 4,1 млн т, в 1965 г. он составил 9,1 млн т, в 1980 г. - 36,6 млн т, в 1991 г. - 37,2 млн т.

Развитие отраслей производства и социальной сферы вызывало необходимость привлечения из других районов страны специалистов и квалифицированных рабочих. Повышалась межрегиональная мобильность коренного насе- 
ления. Рост миграционных потоков вызвал расширение объема пассажирских перевозок. В 1944 г. было перевезено 9,4 тыс. пассажиров, в 1960 г. уже 13,8 млн, а в 1990 г. - 41,3 млн пассажиров. Междугородние автобусные перевозки осуществлялись по 40 маршрутам, включая Абакан, Ак-Довурак, все районные центры; внутри районов автобусы курсировали между райцентром и поселками.

Быстрыми темпами в Туве развивалось дорожное хозяйство. Протяженность автомобильных дорог с твердым покрытием в течение советского периода возросла до 2400 км. Усинский тракт - главная транспортная артерия Тувы, которая еще в 30-40-е годы XX в. была труднопроходимой автогужевой дорогой, в течение короткого времени стала шоссейной трассой общегосударственного значения. В целях сокращения расстояния и затрат на перевозку продукции комбината «Туваасбест» была построена автомобильная дорога Абаза-АкДовурак. Постепенно расширялась сеть местных автодорог, связывающих Кызыл с районными центрами и другими населенными пунктами, в том числе самая протяженная в Туве дорога Кызыл-Тээли. Неотрывной частью транспортной инфраструктуры Тувы стали прирельсовые завозные базы, построенные вблизи железнодорожных станций Абакана, Минусинска, Абазы.

Важнейшим направлением в развитии автодорожного хозяйства было сооружение мостов. В течение продолжительного времени переправа через естественные водные преграды в Туве, даже в Кызыле, осуществлялась с использованием бродов и паромов. Установка в Кызыле в 1957 г. понтонного моста позволила повысить интенсивность движения по автодороге Абакан - Кызыл, в 1963 г. был введен железобетонный мостовой переход через Енисей.

В середине прошлого века заметное место в транспортной системе Тувы занимал речной трансnорm, служивший преимущественно для сплава леса и завоза в восточные районы Тувы горюче-смазочных и строительных материалов, оборудования, различных товаров. В 1950-е годы осуществлялись опытные рейсы по маршруту Красноярск - Чаа-Холь - Кызыл теплоходами «Хакасия», «Туркменистан», «Азербайджан»; теплоход «Кызыл» делал опытные рейсы от Абакана до Шагонара. В 1974 г. было организовано Кызылское районное управление Енисейского пароходства. С 1961 г. для пассажирских перевозок началось применение быстроходных судов с малой осадкой типа «Заря». Хотя число пассажиров, перевезенных речным транспортом, составляло не более $1 \%$ от общего числа пассажиров, для отдаленных районов этот вид транспорта имел ключевое значение.

С 1945 г. начались регулярные воздушные пассажироперевозки. Межрегиональные рейсы из Кызыла в Абакан и Красноярск выполнялись самолетами По-2, Ан-2, в 50-е годы на Ли-2 и Ил-14, позже самолетами Ан-24 и Як-40. Регулярные рейсы стали выполняться также в Барнаул, Иркутск, Кемерово, Новосибирск, Томск, Улан-Удэ и другие города. На местных линиях применялись самолеты Ан-2, Л-410, вертолеты Ми-1 и Ми-8. 
В 1978 г. был впервые выполнен прямой рейс Кызыл - Москва на самолете Ил-18, с 1981 г. использовались самолеты Ту-154. Выполнялись пробные перевозки фруктов и ранних овощей на грузовых самолетах Ил-76. В расчете на 10 тыс. жителей в Тувинской АССР приходилось 7 поездок воздушным транспортом в год - вдвое больше, чем в среднем по стране.

В течение 1970-1980-х годов значительно улучшилось оснащение аэропортов, были построены посадочные площадки, что позволило связать воздушными линиями столицу Тувы со всеми районными центрами и другими населенными пунктами. Аэропорт Кызыла был перебазирован с грунтового на аэродром с твердым покрытием. ВПП с твердым покрытием была построена в Кызыл-Мажалыке, с 1965 г. начались регулярные авиарейсы из этого райцентра в Кызыл и Красноярск. Сформировались специализированные подразделения санитарной авиации, охраны лесов от пожаров и др.

Значительные средства направлялись на создание в Туве соответствующей уровню того времени инфраструктуры связи. Быстро расширялась сеть предприятий почтовой и телеграфно-телефонной связи. К 1990 г. на территории республики функционировало 125 предприятий связи. Активно велось строительство линейных и станционных сооружений связи. В 1963 г. начала вещание Кызылская радиостанция, в 1966 г. был введен в действие телевизионный центр. На первом этапе транслировались местные программы, а с вводом в 1969 г. станции космической связи «Орбита» появилась возможность просмотра программ центрального советского телевидения.

В качестве главной цели экономического развития страны в советский период декларировалось повышение благосостояния народа, что фиксировалось в программных документах правящей Коммунистической партии. Реализация этой цели осуществлялась в форме регулярного роста размера заработной платы рабочих и служащих, пенсий, других выплат. В середине 60-х годов вместо оплаты по трудодням была введена денежная оплата труда колхозников. Все это обусловило рост денежных доходов населения Тувы, которые за 1960-е годы увеличились в 2,7 раза, в течение следующего десятилетия - в 1,8 раза, а в 1980-х гг. их сумма удвоилась.

Возросший платежеспособный спрос требовал динамичного роста товарооборота, расширения ассортимента оказываемых платных услуг. Расширялась сеть торговых предприятий, увеличивалась численность занятых в торговле и общественном питании. Повышался уровень потребления товаров при одновременном изменении его структуры. Особенно заметно возрастало душевое потребление мясомолочных продуктов, яиц, овощей при сокращении в рационе доли картофеля и хлебобулочных изделий. По мере роста доходов в быт населения все чаще входили качественная мебель, бытовая техника, радиоэлектронная аппаратура и транспортные средства. 
Население Тувы за годы советского периода увеличилось в 3,2 раза. Снизилась смертность, повысилась средняя продолжительность жизни. По уровню образования населения, доле специалистов в народном хозяйстве, сетевым показателям социальной инфраструктуры Тува уверенно приближалась, а по некоторым позициям опережала среднероссийский уровень. Так, если в 1959 г. показатель имеющих высшее и среднее (полное и неполное) образование в расчете на 1000 занятых в народном хозяйстве в Туве составлял 66\% от среднего уровня РСФСР, то в 1970 г.- уже почти $82 \%$, в 1979 г. - 91,8\%, а в 1989 г. - уже $96,6 \%$. По количеству больничных коек в расчете на 10 тыс. населения Тува в 1990 г. занимала одно из первых мест в России (193 больничных койки против 137,4 в среднем по РСФСР).

\section{Экономические проблемы советской Тувы}

Достижения в экономическом и социальном развитии советской Тувы являются реальностью, и их перечисление можно было бы продолжать и с большей степенью подробности.

Однако это не дает оснований не замечать имевшихся в экономике республики узких мест, диспропорциий и иных проблем. Их причины и масштабы были различны. Некоторые проблемы экономики Тувы были связаны с особенностями природно-климатического характера или исторического развития Тувы. Другие были вызваны ошибками конкретных управленцев разного уровня (например, размещение производств, полностью базировавшихся на привозном сырье). Разумеется, ряд проблем был присущ социалистической формации как таковой. В условиях административно-командной системы и директивноплановой экономики, несмотря на декларировавшиеся с середины 1960-х гг. (в ходе т. н. «косыгинской реформы») принципы «социалистического хозрасчета», повышение эффективности и рентабельности производства, производительности труда, фондоотдачи фактически не были приоритетными целями.

Высокий уровень затрат компенсировался внутриотраслевым, в рамках отраслевых министерств СССР и РСФСР, перераспределением финансовых ресурсов, применением системы поясных закупочных цен в сельском хозяйстве, наконец, прямым дотированием предприятий, которые работали с убытками, однако вопрос об их реконструкции, тем более, закрытии не ставился. Одной из экономических проблем была чрезмерно высокая зависимость от поставок «из-за Саян» различных ресурсов при не слишком надежной транспортной инфраструктуре. Местное производство товаров народного потребления не удовлетворяло потребностей населения.

Не нашли кардинального решения энергетическая и транспортная проблемы. В результате ориентации на получение энергии из-за Саян не получила раз- 
вития генерация электроэнергии. Тува осталась энергозависимым регионом с долей собственного производства электроэнергии не выше $10 \%$. Не удалось добиться строительства железной дороги, а густота автодорожной сети в Туве даже в 1980-е гг. была в 2,5 раза ниже среднероссийского показателя. Бюджетные капиталовложения не были в полном объеме обеспечены материальными ресурсами, распылялись на множество строек, в связи с чем к началу 1990-х гг. в Туве оставались незавершенными несколько сотен строительных объектов.

В течение десятилетий сложился порядок формирования республиканского и местных бюджетов преимущественно на дотационной основе. Структура экономического потенциала республики имела специфические особенности, осложнявшие его адаптацию к рыночному изменению условий хозяйствования. В связи с этим экономические катаклизмы, пережитые всеми регионами России, для Тувы оказались гораздо более масштабными и тяжелыми. Драматический для экономики период спада объемов производства и деиндустриализации завершился только к концу 1990-х гг.

К середине 2010-х гг. на фоне изменившейся конъюнктуры мирового и российского сырьевых рынков крупные российские и иностранные компании стали проявлять интерес к освоению недр Тувы, прежде всего, каменного угля и цветных металлов. Начался процесс восстановления сельскохозяйственных предприятий. Увеличился объем и изменилась структура капиталовложений, при этом существенно возросли объемы внебюджетных, в т. ч. иностранных инвестиций. Возросли среднедушевые доходы населения, показатели розничного товарооборота и платных услуг, улучшились сетевые показатели социальной сферы. Однако в целом позитивный экономический процесс проходил медленно, в вялотекущем режиме и натуральные показатели выпуска многих видов продукции ко второму десятилетию XXI в. едва достигали уровня 19601970-х гг.

Анализ экономических достижений советской Тувы и проблем, сложившихся в тот период, позволяет сделать некоторые обобщения, которые следовало бы учесть при определении стратегии развития республики в XXI веке.

В целом советский период, особенно в 1960-1980-е годы, имел для экономики Тувы позитивный характер и был временем наиболее быстрого развития хозяйственного комплекса. За счет государственных инвестиций создавались предприятия и целые отрасли производства, были намечены контуры специализации республики. Экономические показатели ежегодно возрастали, при этом часто были выше, чем в среднем по стране. Созданная производственная инфраструктура - транспортная, энергетическая, инженерная - используется без серьезной реконструкции в течение многих лет постсоветского периода. Многие конкретные факты экономической жизни советской Тувы - широкая номенклатура производимой продукции и объемы, многократно превышающие современный уровень, грузоперевозки по Енисею от Кызыла до Абака- 
на и Красноярска, прямые авиарейсы в Москву и столицы республик Средней Азии, дефицит рабочей силы, реальное движение очереди на получение жилья и многое другое - сегодня представляются невероятными.

Проблемы того времени имели различное происхождение и масштабы. Относительно благополучное функционирование хозяйства Тувы обеспечивалось только в условиях директивного планирования, государственного регулирования цен, фондированных потоков материально-технических ресурсов и потребительских товаров, других атрибутов социалистической плановой экономики.

Эти проблемы наряду с некоторыми особенностями хозяйства обусловили ненадежность, неустойчивость экономики Тувы. При первых порывах «рыночных ветров» были утрачены необходимые условия функционирования предприятий и целых отраслей.

\section{Учет уроков советской экономики при формировании}

\section{долгосрочной стратегии развития Тувы}

Социально-экономическое положение Тувы в начале XXI века остается достаточно сложным. Некоторые проявившиеся еще в советское время проблемы усугубились, другие превратились в свою противоположность - безработица вместо дефицита рабочей силы, проблемы сбыта продукции вместо дефицита ресурсов и т. д. Формируемые в Туве доходы бюджета, как и в советское время, не позволяют в полном объеме обеспечивать функционирование социальной сферы.

Хотя действие программных документов, принятых в начале 2000-х годов, в частности, Стратегии социально-экономического развития Республики Тыва до 2020 года (2007 г.) еще не завершилось, экономическая конъюнктура, конфигурация действующих в Туве основных хозяйствующих субъектов изменились таким образом, что возникла необходимость обновления долгосрочной стратегии социально-экономического развития с учетом требований, предъявляемых Федеральным законом «О стратегическом планировании в Российской Федерации», соответствующим законом Республики Тыва к региональным стратегиям социально-экономического развития.

Очевидно, что большая часть применяемых в советский период механизмов развития экономики в настоящее время не действует и необходимо применение иных организационных и финансовых инструментов. Представляются неэффективными и поэтому нецелесообразными попытки возобновления некоторых производств, успешно действовавших в условиях плановой социалистической экономики. Не следует рассчитывать на бюджетные инвестиции в развитие производства. Желательно воздержаться от реализации проектов, окупаемость которых сомнительна, а также отказаться, хотя бы на время, от 
дорогостоящих крупных социальных объектов, приносящих дополнительные расходы.

Крайне важной является координация действий с федеральными управленческими структурами и правильное определение роли и места Тувы в реализации федеральных отраслевых стратегий и долгосрочных программ. Однако этому вопросу уделяется явно недостаточное внимание.

Так, в июне 2017 г. был проведен форум «Тува будущего: стратегия перемен» (официальный сайт http://tuva-2030.ru/). Предполагалось, что будут обсуждены подходы и определены контуры новой долгосрочной стратегии развития Тувы. K сожалению, в отличие от научно-практических конференций и совещаний советского периода форум носил в большей степени общественный, чем научный и управленческий характер. Акцент был сделан преимущественно на социально-гуманитарных проблемах - развитии человеческого капитала, здравоохранения, культуры, молодежной политики и др.

Остается дискуссионным вопрос о главной цели развития экономики республики. Представляется неудачными такие формулировки, как «построение самодостаточной экономики», в силу размытости и неоднозначности самого термина, или «уход от дотационности», что является узко финансовой категорией. Впрочем, эти проблемы вызваны т. н. «кризисом целеполагания», который в России пока не преодолен и на общегосударственном уровне.

Практически не рассматривались проекты стратегий социально-экономического развития муниципальных образований. Не были высказаны и обсуждены позиции Минэкономразвития РФ, Минпромторга, Минсельхоза и других федеральных структур относительно роли Тувы в реализации отраслевых стратегий и поддержки ее проектов из федерального бюджета. Между тем, как для республики, так и для потенциальных внешних инвесторов, крайне важно знать, например, статус месторождений Тувы в рамках разрабатываемой Минприроды РФ Стратегии развития минерально-сырьевой базы России до 2035 г., или транспортных проектов в аналогичном документе Минтранса РФ. В противном случае велик риск того, что республиканская стратегия станет суммой локальных проектов, предлагаемых муниципалитетами.

Следует отметить, что продвижение инвестиционных проектов Тувы осуществляется Правительством Республики Тыва в рамках реализации мероприятий Плана по социально-экономическому развитию Республики Тыва на 2015-2025 годы, утвержденного Правительством России в 2015 г. Однако это не снижает значения долгосрочной стратегии социально-экономического развития республики, согласованной на федеральном уровне. 


\section{СПИСОК ЛИТЕРАТУРЫ}

Балакина, Г. Ф., Бегзи, А. Д. (2016) Экономика Тувы: возможные стратегии развития. Кызыл : ТувИКОПР СО РАН. 380 с.

История Тувы (1964) : в 2 т. / [редколлегия: Л. П. Потапов (отв. ред.) и др.]. М. : Наука. Т. 2. 455 с.

История Тувы (2016) : в 3 т. / отв. ред. В. А. Ламин. Новосибирск : Наука. Т. 3. 455 c.

Республика Тыва. История в цифрах (2011) : стат. сборник. Кызыл : [б. и.]. 114 c.

Труды регионального совещания по развитию производительных сил Тувинской автономной области (1960). Новосибирск : Изд. Сиб. отд. АН СССР. 320 с.

Развитие народного хозяйства Тувинской АССР в десятой пятилетке и в перспективе до 1990 года (1975) : (Материалы Науч.-практ. конф., состоявшейся 2-4 июля 1974 г.) / ред. коллегия: А. Г. Аганбегян (отв. ред.) [и др.]. Кызыл : [б. и.]. 353 c.

Проблемы комплексного развития производительных сил Тувинской АССР (1981): Материалы регионального научно-практического совещания, состоявшегося 3-5 апреля 1980 г. / ред. коллегия: Г. Ч. Ширшин (отв. ред.) [и др.]. Кызыл : [б. и.]. 282 с.

Проблемы развития производительных сил Тувинской АССР на период до 2005 года и основные направления дальнейшего развития ее минерально-сырьевой базы (1988): Материалы научно-практического совещания, состоявшегося 12-13 августа 1988 г. / ред. коллегия: Г. Н. Долгополов (отв. ред.) [и др.]. Кызыл : [б. и.]. 244 с.

Тува за 80лет (2001) : юбилейный стат. сборник. Кызыл : [б. и.]. 120с.

Юбилейный статистический сборник к 100-летию единения России и Тувы (2014). Кызыл : Тывастат. 208 с.

Экономика Тувинской АССР (1973) / ред. коллегия: С. В. Клопов (отв. ред.) [и др.]. Кызыл : Тувинское книжное издательство. 378 с.

Дата поступления: 29.09.2017 2.

\section{REFERENCES}

Balakina, G. F. and Begzi, A. D. (2016) Ekonomika Tuvy: vozmozhnye strategii razvitiia [The economy of Tuva: possible strategies of development]. Kyzyl, TuvIKOPR SO RAN. 380 p. (In Russ.).

Istoriia Tuvy [The History Of Tuva] (1964) : in 2 vols. / [Editorial Board: L. P. Potapov (ed.) et al.]. Moscow, Nauka. Vol. 2. 455 p. (In Russ.). 
Istoriia Tuvy [The History Of Tuva] (2016) : in 3 vols. / ed. by V. A. Lamin. Novosibirsk, Nauka. Vol. 3. 455 p. (In Russ.).

Respublika Tyva. Istoriia v tsifrakh [The Republic of Tyva: History in numbers] (2011): statistical compendium. Kyzyl, [b. i.]. 114 p. (In Russ.).

Trudy regional'nogo soveshchaniia po razvitiiu proizvoditel'nykh sil Tuvinskoi avtonomnoi oblasti [Proceedings of the regional conference on developing the forces of production in Tuvan Autonomous Oblast] (1960). Novosibirsk : Izd. Sib. otd. AN SSSR. 320 p. (In Russ.).

Razvitie narodnogo khoziaistva Tuvinskoi ASSR v desiatoi piatiletke i v perspektive do 1990 goda [The development of national economy in Tuvan ASSR in 10th Five-year plan and up to the year 1990] (1975) : (Proceedings of research conference, 2-4 July 1974) / Editorial Board: A. G. Aganbegian (ed.) [et al.]. Kyzyl, [s. p.]. 353 p. (In Russ.).

Problemy kompleksnogo razvitiia proizvoditel'nykh sil Tuvinskoi ASSR [Problems of complex development of productive forces in the Tuvan ASSRJ (1981) : Proceedings of regional research conference, 3-5 April 1980 / Editorial Board: G. Ch. Shirshin (ed.) [et al.]. Kyzyl, [s. p.]. 282 p. (In Russ.).

Problemy razvitiia proizvoditel'nykh sil Tuvinskoi ASSR na period do 2005 goda $i$ osnovnye napravleniia dal'neishego razvitiia ee mineral'no-syr'evoi bazy [Issues of development of the productive forces in the Tuvan ASSR in the period up to 2005 and the main directions of further development of its mineral resource base] (1988) : Proceedings of regional research conference, 12-13 August 1988 / Editorial Board: G. N. Dolgopolov (ed.) [et al.]. Kyzyl, [s. p.]. 244 p. (In Russ.).

Tuva za 80 let [Tuva over 80 years] (2001) : anniversary statistical collection. Kyzyl, [b. i.]. 120 p. (In Russ.).

Iubileinyi statisticheskii sbornik $k$ 100-letiiu edineniia Rossii $i$ Tuvy [A collection of statistics for the 100th anniversary of the unification of Russia and Tuva] (2014). Kyzyl, Tyvastat. 208 p. (In Russ.).

Ekonomika Tuvinskoi ASSR [The economy of the Tuvan ASSR] (1973) / Editorial Board: S. V. Klopov (ed.) [et al.]. Kyzyl, Tuvinskoe knizhnoe izdatel'stvo. 378 p. (In Russ.).

Submission date: 29.09.2017.

\section{Для цитирования:}

Бегзи А. Д. Экономика советской Тувы: достижения, проблемы и уроки [Электронный ресурс] // Новые исследования Тувы. 2017, № 4. URL: https://nit.tuva.asia/nit/ article/view/740 (дата обращения: дд.мм.гг.). DOI: 10.25178/nit.2017.4.5

\section{For citation:}

Begzi A. D. The economy of the soviet Tuva: achievements, challenges and lessons. The New Research of Tuva, 2017, no. 4 [on-line] Available at: https://nit.tuva.asia/nit/article/ view/740 (accessed: ...). DOI: 10.25178/nit.2017.4.5 